\title{
Pancreatic digestive hydrolase activities in growing rats fed alternately on raw and heated soya-bean flour
}

\author{
BY FATIMA KHALIFA, JOSIANE PROST AND JACQUES BELLEVILLE* \\ Université de Bourgogne, Unité de Nutrition Cellulaire et Métabolique, Faculté des Sciences \\ Mirande, B.P. 138, 21004 Dijon cedex, France \\ AND LOUIS SARDA \\ Université de Provence, Laboratoire de Biochimie, Faculté des Sciences St Charles, Place Victor \\ Hugo, 13331 Marseille cedex 3, France
}

(Received 22 July 1993 - Revised 4 January 1994 - Accepted 14 January 1994)

\begin{abstract}
The time-course effects of two diets containing raw (RSF) or heated (HSF) soya-bean flour on the digestive enzyme levels in the pancreas and in pancreatic juice were investigated in growing rats fed, alternately, on RSF or HSF diets for two 4-week periods. These values were compared with those obtained in a control group fed on a casein diet. RSF and HSF diets lowered $N$ balance (84.8 (SE 0.9), 82.6 (SE 0.8) and 79.9 (SE 0.8) \% with control, HSF and RSF diets respectively, at the third week). However, they increased protease activities compared with the control diet (3-fold for trypsin $(E C$ 3.4.21.4) and chymotrypsin $(E C$ 3.4.21.1) activities in pancreas contents and outputs with the RSF diet; 2-fold for trypsin in pancreas contents and outputs and by $60 \%$ for chymotrypsin contents with the HSF diet). The poorer nutritional $\mathrm{N}$ utilization might be attributable to soya-bean flour heatstable (lectins) and heat-labile components (trypsin inhibitors). The decrease in lipid apparent digestibilities in RSF and HSF diets (97.0 (SE 0.8), 91.1 (SE 0.9) and 90.4 (SE 0.7) \% with control, RSF and HSF diets at the seventh week) were correlated with a diminution in apparent lipase (EC 3.1.1.3; measured without addition of exogenous colipase), potential lipase (measured with addition of saturated amounts of exogenous colipase) and colipase activities. Compared with control values, gains in potential and apparent lipase outputs were diminished by nearly $40 \%$ and gain in colipase outputs by $60 \%$ with RSF and HSF diets. These results show clearly that heated or raw soya-bean flours have a significant inhibitory effect on lipase digestive enzyme activities in the pancreas and in its secretion, which might explain impaired lipid digestibility.
\end{abstract}

Soya-bean flour: Pancreas: Lipase: Phospholipase $\mathbf{A}_{2}$

Soya-bean flour contains antinutritional factors. Protease inhibitors found in raw soyabean flour (RSF) have been extensively studied. It is well established that giving RSF to rats causes growth depression, pancreatic enlargement and stimulation of its secretory activity (Liener \& Kakade, 1980). Most of the deleterious effects of RSF have been generally attributable to trypsin inhibitor (TI; MacGuiness et al. 1984). However, rats fed on diets supplemented with soya-bean flours devoid of TI activity also developed pancreatic hypertrophy (Naim et al. 1982). This effect can be partly attributed to the low digestibility of RSF proteins which favours the formation of highly stable complexes between proteases and proteins and disturbs the negative feedback regulation of cholecystokinin (CCK) secretion (Liener, 1981).

In vitro studies have shown that RSF contains compounds that inhibit pancreatic lipase

* For reprints. 
Table 1. Composition of the diets $(\mathrm{g} / \mathrm{kg})^{*}$

\begin{tabular}{|c|c|c|c|}
\hline & Ingredients & Control diet & $\begin{array}{c}\text { Raw or heated } \\
\text { soya-bean flour } \\
\text { diets }\end{array}$ \\
\hline Protein & $\begin{array}{l}\text { Milk casein } \dagger \\
\text { Soya-bean protein } \ddagger\end{array}$ & 200 & $\overline{200}$ \\
\hline Carbohydrates & $\begin{array}{l}\text { Maize starch§ } \\
\text { Soya-bean carbohydrates } \ddagger\end{array}$ & $562 \cdot 2$ & $\begin{array}{l}437 \cdot 5 \\
125\end{array}$ \\
\hline Lipids & $\begin{array}{l}\text { Soya-bean triacylglycerols } \\
\text { Soya-bean phospholipids }\end{array}$ & $\begin{array}{r}102 \\
8\end{array}$ & $\begin{array}{c}102 \ddagger \\
8\end{array}$ \\
\hline Fibres & $\begin{array}{l}\text { (Agar-agar) } \\
\text { Soya-bean fibre } \\
\text { Cellulose } \|\end{array}$ & $\frac{40}{26}$ & $\begin{array}{l}22 \cdot 5 \\
17 \cdot 5 \\
26\end{array}$ \\
\hline Others & $\begin{array}{l}\text { Salt mix } \\
\text { Vitamin mix** } \\
\text { Moisture }\end{array}$ & $\begin{array}{c}28 \cdot 3 \\
5 \cdot 7 \\
40\end{array}$ & $\begin{array}{c}28 \cdot 3 \\
5 \cdot 7 \\
40 \pm\end{array}$ \\
\hline
\end{tabular}

* Diets were isoenergetic $(16.9 \mathrm{MJ} / \mathrm{kg})$ and were given in powdered form.

$\uparrow$ Prolabo (Paris, France).

$\ddagger$ Ingredients originating from soya-bean flour (Soyapan, Edelsoja GMBH, 2000 Hamburg, Germany).

$\S$ Etablissements Louis François (Saint Maur les Fossés, France).

II Cellulose originating from vitamin and salt mixtures.

If UAR, 205B (Villemoisson, Epinay sur Orge, France). The salt mix provides the following amounts (mg/kg diet): $\mathrm{CaHPO}_{4} 17200, \mathrm{KCl} 4100, \mathrm{NaCl} 4000, \mathrm{MgO} 420, \mathrm{MgSO}_{4} 2000, \mathrm{Fe}_{2} \mathrm{O}_{3} 120, \mathrm{Fe}_{2} \mathrm{SO}_{4} \cdot 7 \mathrm{H}_{2} \mathrm{O} 200$, trace elements $400\left(\mathrm{MnSO}_{4} \cdot \mathrm{H}_{2} \mathrm{O} 98, \mathrm{CuSO}_{4} \cdot 5 \mathrm{H}_{2} \mathrm{O} 20, \mathrm{ZnSO}_{4} \cdot 7 \mathrm{H}_{2} \mathrm{O} 80, \mathrm{CoSO}_{4} \cdot 7 \mathrm{H}_{2} \mathrm{O} 0 \cdot 16, \mathrm{KI} 0 \cdot 3\right)$.

** UAR 200 vitamin mixture, containing (mg/kg diet): retinol 12 , cholecalciferol $0 \cdot 125$, thiamin 40 , riboflavin 30 , pantothenic acid 140 , pyridoxine 20 , inositol 300 , cyanocobalamin 01 , ascorbic acid 1600 , DL- $\alpha$-tocopherol 340 , menadione 80 , nicotinic acid 200, choline 2720 , pteroylmonoglutamic acid $10, p$-aminobenzoic acid 100 , biotin $0 \cdot 6$.

(EC 3.1.1.3) and which are heat labile proteins (Satouchi \& Matsushita, 1976). Inhibitors of pancreatic lipase have been partially purified in protein fractions isolated from RSF (Widmer, 1977).

Gargouri et al. (1984) have shown that lipase inhibition by proteins, including soya-bean flour proteins, does not result from the formation of a soluble complex between enzyme and inhibitor, but from the fact that proteins bound to the oil-water interface prevent enzyme interaction with their substrate. The extent to which this inhibitory effect of proteins might affect enzymic digestion of dietary fat has not been studied in vivo. However, in a previous short-term study we have shown that soya-bean-flour components, which are partially thermolabile, decrease lipid digestion and absorption (Khalifa et al. 1992).

The effects of lipase inhibitors, previously characterized in soya-bean flour, on the synthesis and secretion of pancreatic lipolytic enzymes and on fat digestion in rats fed on RSF or heated soya-bean flour (HSF) diets were investigated. In relation to this, apparent and potential lipase, colipase and phospholipase $\mathrm{A}_{2}(E C 3.1 .1 .4)$ activities, in parallel with protease activities (trypsin (EC 3.4.21.4) and chymotrypsin (EC 3.4.21.1)), were measured in the pancreas and in its secretion. Experiments were carried out in growing animals for two 4-week periods with RSF and HSF diets being fed alternately. Comparisons were performed using a reference diet containing $200 \mathrm{~g}$ casein $/ \mathrm{kg}$. 


\section{EXPERIMENTAL}

\section{Animal and diets}

Male Wistar rats ( $n$ 180; Iffa-Credo, L'Arbresle, France), weighing 80 (SE 5) g at the beginning of the experiment, were given a balanced control diet $(200 \mathrm{~g}$ casein $/ \mathrm{kg}$ ) for 1 week. After this adaptation period their weight was 100 (SE 8) g. They were then divided into three equal groups and fed on different diets as follows: the S1 group were fed on a HSF diet for one 4-week period (phase 1) followed by a RSF diet for a second 4-week period (phase 2); the S2 group were fed on the RSF diet during phase 1 and the HSF diet during phase 2; a control group (C) was fed on the original reference diet throughout the experiment ( 8 weeks). Diets were isoenergetic $(16.9 \mathrm{MJ} / \mathrm{kg}$ ) and were given in powdered form. The composition of the diets is shown in Table 1. Rats were kept in wire-bottomed cages at constant temperature $\left(25^{\circ}\right)$ and humidity $(65 \%)$ with light provided for $12 \mathrm{~h}$ daily (07.00-19.00 hours). They had ad lib. access to food and tap water. The general guidelines for the care and use of laboratory animals were followed (Council of European Communities, 1986).

Commercially available soya-bean flour (Soyapan) was purchased from Edelsoja (Hamburg, Germany). HSF was obtained by autoclaving RSF at $130^{\circ}$ for 9 min, under pressure ( 1.5 bar). Under these experimental conditions, only $21 \%$ of the trypsin inhibitor activity originally present in RSF remained in HSF (Khalifa et al. 1992) and this residual activity had no antinutritional effect (Rackis, 1981). HSF contained $30 \%$ of the pancreatic lipase inhibitor activity found in RSF (Gargouri et al. 1984). The fatty acid composition $(\%)$ of total lipids in soya-bean flour was : palmitic $12 \cdot 4$, stearic $2 \cdot 8$, oleic $18 \cdot 9$, linoleic $57 \cdot 7$, and linoleic $8 \cdot 1$. After heating, the fatty acid composition remained unchanged.

Food intake and body weight were measured daily on six rats from each group. To determine the nutritional efficiency of diets, faeces and urine were collected and pooled for several 1-week periods. $\mathrm{N}$ balance is the ratio between $\mathrm{N}$ retained and $\mathrm{N}$ ingested, and lipid digestibility is the ratio between lipid ingested and lipid excreted in faeces, as follows:

$$
\begin{array}{r}
\mathbf{N} \text { balance }=\frac{\mathbf{N} \text { ingested }-\mathbf{N} \text { excreted }(\text { urinary }+ \text { faecal })}{\mathbf{N} \text { ingested }} \times 100, \\
\text { lipid digestibility }=\frac{\text { lipid ingested }- \text { lipid excreted }(\text { faecal })}{\text { lipid ingested }} \times 100 .
\end{array}
$$

The food and protein conversion efficiency ratios were determined as follows:

$$
\begin{aligned}
\text { food conversion efficiency ratio } & =\frac{\text { gain in body weight }(\mathrm{g})}{\text { food intake }(\mathrm{g}),} \\
\text { protein conversion efficiency ratio } & =\frac{\text { gain in body weight }(\mathrm{g})}{\text { protein intake }(\mathrm{g}) .}
\end{aligned}
$$

\section{Pancreas and pancreatic juice samples}

At days 2, 7, 14, 21 and 28 of each phase (1 and 2), six rats from each group were anaesthetized with Imalgene (Iffa-Mérieux, Lyon, France; $100 \mathrm{mg} / \mathrm{kg}$ body weight injected intraperitoneally) and fitted with a double pancreatic and biliary cannula, according to the technique of Colwell (1951), to obtain pure pancreatic juice. After $6 \mathrm{~h}$ fasting, pancreatic juice was collected on ice for $24 \mathrm{~h}$. During the sampling period, rats were fasted but had access ad lib. to tap water containing $\mathrm{NaCl}(120 \mathrm{~mm})$ and $\mathrm{CaCl}_{2}(27 \mathrm{~mm})$. No bile or pancreatic juice was re-introduced into the intestinal lumen. Then the pancreas was 
removed, washed with $\mathrm{NaCl}(150 \mathrm{~mm})$, trimmed free of fat, weighed, diluted with ice-cold water $(1 \mathrm{ml} / 100 \mathrm{mg}$ tissue) and homogenized using a Potter-Elvejhem homogenizer (Braun, Helsungen AG, Germany) to obtain pancreatic extracts. Portions of pancreatic juice and pancreas extracts were kept at $-30^{\circ}$ until assayed.

\section{Chemical analysis and enzyme activity determination}

Protein levels were determined according to the technique of Lowry et al. (1951) using bovine serum albumin as standard. Total lipids of faeces were extracted for analysis by the method of Folch et al. (1957).

Enzyme activities were assayed on specific substrates by titrimetry, using a pH-stat Radiometer (Radiometer Analytical Instruments Division, Copenhagen, Denmark).

Trypsin activity was determined by measuring the hydrolysis of $N$-benzoyl-L-arginine ethyl ester hydrochloride and that of chymotrypsin by degradation of $N$-acetyl-L tyrosine ethyl ester monohydrate, after activation of the proenzyme forms by exogenous trypsin, using the method of Figarella (1966). The production of free amino acids was automatically neutralized by $20 \mathrm{~mm}-\mathrm{NaOH}$ solution.

Triacylglycerol lipase (apparent and potential) and colipase activities were assayed according to the technique of Rathelot et al. (1975), using a triolein substrate. Apparent lipase activity was measured without addition of colipase to the incubation medium, and potential lipase activity with a saturating amount of colipase, i.e. $5 \mu \mathrm{g}$ crude exogenous porcine colipase, because there is evidence that colipase from one species activates the lipase of other species (Canioni et al. 1977).

Determination of colipase requires previous lipase inactivation of pancreatic juice and pancreas extracts. This was achieved by lowering the $\mathrm{pH}$ of samples to 2.0 at $0^{\circ}$ for $10 \mathrm{~min}$, then restoring it to $\mathrm{pH} 9.0$ with $\mathrm{NaOH}(100 \mathrm{~mm})$. Portions of acid-treated samples of pancreatic juice $(100 \mu \mathrm{l})$ or pancreas $(500 \mu \mathrm{l})$ were added to an assay system mixture containing bile salts and a purified preparation of rat lipase $(40 \mathrm{U})$ devoid of colipase (Ouagued \& Girard-Globa, 1980), then lipase activity was measured. Colipase was determined in terms of its ability to restore lipase activity.

Phospholipase $\mathrm{A}_{2}$ was determined according to the method of Belleville \& Clement (1971), using egg yolk phospholipids as substrate. Triolein and phospholipid hydrolyses were measured for 10 and $20 \mathrm{~min}$ respectively. The production of free fatty acids was automatically neutralized by a $20 \mathrm{~mm}-\mathrm{NaOH}$ solution.

One enzyme unit corresponds to $1 \mathrm{mmol}$ substrate hydrolysed/min at the appropriate $\mathrm{pH}$ and temperature.

Results were expressed as their arithmetical means with their standard errors. Values are means of gain in activity per pancreas per day (for contents and outputs) during phases 1 and $2(\Delta($ day $2-$ day 7$), \Delta($ day 7 -day 14$), \Delta($ day 14 day 21$), \Delta($ day $21-$ day 28$))$.

\section{Statistical analysis}

Statistical analysis was performed on control, S1 and S2 groups during phases 1 and 2, using a simple crossover design (Armitage \& Berry, 1987) e.g. $\Delta 1$ (day 7 -day 14 phase 1) $-\Delta 2$ (day 7-day 14 phase 2); Student's $t$ test was carried out on the $\Delta 1-\Delta 2$ values. The significance of the difference is given by $t$ and $P$ values.

\section{RESULTS}

Body weights and food intake

Compared with control values, at the end of phase 1 the weight of rats fed on the HSF (S1) or RSF (S2) diets dropped to 82 and $74 \%$ respectively (Fig. 1). These values remained lowered during phase 2 , and at the end of this phase the weights of rats fed on both soya- 

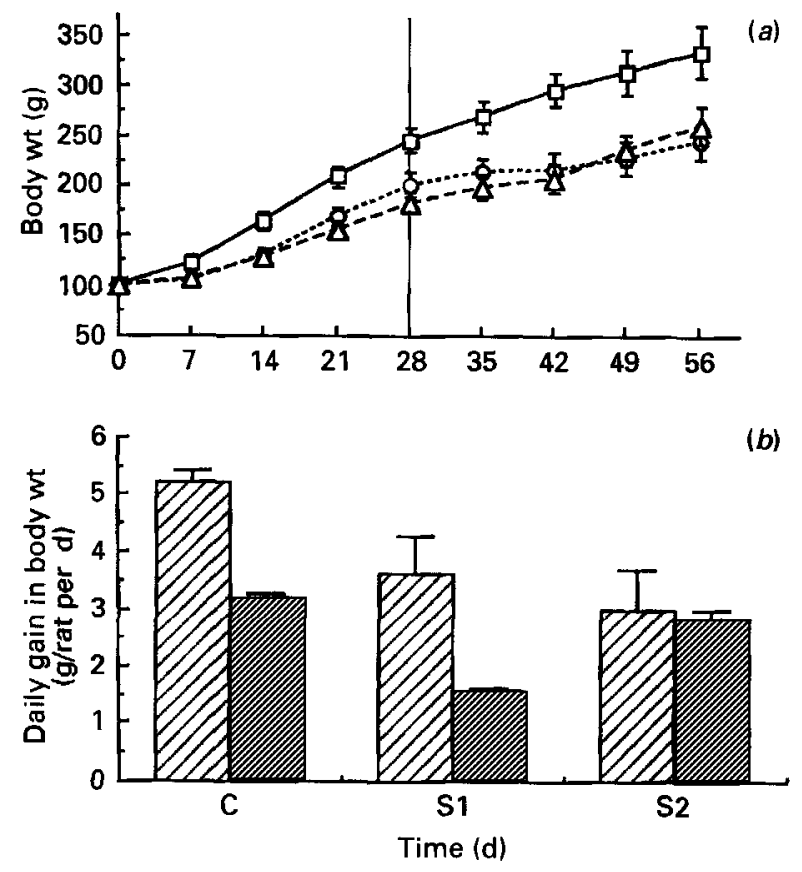

Fig. 1. Effect of alternate feeding of diets containing raw (RSF) or heated (HSF) soya-bean flour on (a) body weight and $(b)$ daily gain in body weight in rats. Rats were given one of the diets for $28 \mathrm{~d}$ (phase 1 ) then changed onto the alternate diet for a further $28 \mathrm{~d}$ (phase 2); the point of change is indicated in panel (a) by a vertical line. Values are means with their standard errors indicated by vertical bars. ( $-\square-$ ), control (C) group fed on a diet containing $200 \mathrm{~g}$ casein $/ \mathrm{kg}$ for $56 \mathrm{~d}$; (--O--), S1 group, fed on the HSF diet during phase 1 and the RSF diet during phase $2 ;\left(--\triangle_{--}\right), \mathrm{S} 2$ group, fed on the RSF diet during phase 1 and the HSF diet during phase $2 ;(\square)$, phase 1; (res), phase 2. Statistical analysis (Student's $t$ test): C v. S1, $t 12 \cdot 56, P<0.001 ; \mathrm{C} v . \mathrm{S} 2, t 11 \cdot 12, P<0.001$; $S 1 v . \mathbf{S} 2, t 12.09, P<0.001$. For details of diets and procedures, see Table 1 and pp. 535536.

bean flours were only $70 \%$ of control values. After the diet change the body weight curves of rats fed on the raw and heated soya-bean flours intersected between day 42 and day 49 of the experiment. Gains in body weight were significantly different between all three dietary groups (Fig. 1).

During each phase, the lowest food intakes/d per rat (Table 2) were obtained with the RSF diet (S2 during phase 1 and S1 during phase 2).

\section{$N$ balance and apparent lipid digestibility (Table 2)}

In the control group, $\mathrm{N}$ balance values were unchanged with age. $\mathrm{N}$ balances were higher in rats fed on the HSF diet than in those fed on the RSF diet, but these $\mathbf{N}$ balance values were lower than those of the control group.

The highest values of lipid digestibility were obtained in the control group and remained steady throughout the experiment ( 97 (SE 0.5) \%). Values were higher with the RSF than with the HSF diet.

\section{Food and protein conversion efficiency ratios (Table 3)}

Compared with control values, during phase 1 both food and protein conversion efficiency ratios (Table 3) were lowered by soya-bean flours ( -25 and $-30 \%$, with HSF and RSF diets respectively), whereas during phase 2 these values were diminished with RSF $(-26 \%)$, but increased with HSF $(+17 \%)$. 
Table 2. Food intake, $N$ balance and lipid digestibility in rats fed on a control diet $(C)$ for $56 d$, or fed alternately on diets containing raw soya-bean flour (RSF) or heated soya-bean flour (HSF) for 28 d each in cross-over design*

(Mean values with their standard errors for six rats)

\begin{tabular}{|c|c|c|c|c|c|c|c|}
\hline \multirow{2}{*}{$\begin{array}{l}\text { Stage of } \\
\text { experiment }\end{array}$} & \multirow[b]{2}{*}{ Group } & \multicolumn{2}{|c|}{$\begin{array}{l}\text { Food intake } \\
\text { ( } \mathrm{g} / \mathrm{d} \text { per rat) }\end{array}$} & \multicolumn{2}{|c|}{$\mathrm{N}$ balance $(\%)$} & \multicolumn{2}{|c|}{$\begin{array}{l}\text { Lipid digestibility } \\
\qquad(\%)\end{array}$} \\
\hline & & Mean & $\mathrm{SE}$ & Mean & $\mathbf{S E}$ & Mean & SE \\
\hline $\begin{array}{l}\text { Week } 3 \\
\text { (phase 1) }\end{array}$ & $\begin{array}{l}\mathrm{C} \\
\mathrm{S} 1 \dagger \mathrm{HSF} \\
\mathrm{S} 2 \dagger \mathrm{RSF}\end{array}$ & $\begin{array}{l}23 \cdot 4 \\
21 \cdot 1 \\
13 \cdot 4\end{array}$ & $\begin{array}{l}1.50 \\
0.31 \\
0.25\end{array}$ & $\begin{array}{l}86 \cdot 0 \\
79 \cdot 8 \\
65 \cdot 3\end{array}$ & $\begin{array}{l}0 \cdot 7 \\
0 \cdot 6 \\
0 \cdot 3\end{array}$ & $\begin{array}{l}97 \cdot 5 \\
79 \cdot 7 \\
86 \cdot 4\end{array}$ & $\begin{array}{l}0.8 \\
0.5 \\
0.7\end{array}$ \\
\hline $\begin{array}{l}\text { Week } 7 \\
\text { (phase 2) }\end{array}$ & $\begin{array}{l}\text { C } \\
\text { S1 RSF } \\
\text { S2 HSF }\end{array}$ & $\begin{array}{l}31 \cdot 4 \\
18 \cdot 9 \\
23 \cdot 6\end{array}$ & $\begin{array}{l}2 \cdot 59 \\
1 \cdot 16 \\
1 \cdot 89\end{array}$ & $\begin{array}{l}84 \cdot 8 \\
79 \cdot 9 \\
82 \cdot 6\end{array}$ & $\begin{array}{l}0.9 \\
0.7 \\
0.8\end{array}$ & $\begin{array}{l}97 \cdot 0 \\
91 \cdot 1 \\
90 \cdot 4\end{array}$ & $\begin{array}{l}0.8 \\
0.9 \\
0.7\end{array}$ \\
\hline C v. Sl & & \multicolumn{2}{|c|}{$\begin{array}{c}t 5.339 \\
P<0.001\end{array}$} & \multicolumn{2}{|c|}{$\begin{array}{c}t 2.95 \\
0.001<P<0.01\end{array}$} & \multicolumn{2}{|c|}{$t 2 \cdot 34$} \\
\hline $\mathrm{C} v . \mathrm{S} 2$ & & \multicolumn{2}{|c|}{$\begin{array}{c}t 4.989 \\
P<0.001\end{array}$} & \multicolumn{2}{|c|}{$\begin{array}{c}t 9.72 \\
P<0.001\end{array}$} & \multicolumn{2}{|c|}{$\begin{array}{c}t 2.43 \\
0.02<P<0.05\end{array}$} \\
\hline $\mathrm{S} 1$ v. $\mathrm{S} 2$ & & \multicolumn{2}{|c|}{$\begin{array}{c}t 5.952 \\
P<0.001\end{array}$} & \multicolumn{2}{|c|}{$\begin{array}{c}t 5.659 \\
P<0.001\end{array}$} & \multicolumn{2}{|c|}{$\begin{array}{c}t 9.73 \\
P<0.001\end{array}$} \\
\hline
\end{tabular}

* For details of diets and procedures, see Table 1 and pp. 535-536.

$\dagger$ Group S1 received the HSF diet during phase 1 and the RSF diet during phase 2; group S2 received the RSF diet during phase 1 and the HSF diet during phase 2 .

Table 3. Food and protein conversion efficiency ratios in rats fed on a control diet (C) for $56 d$, or fed alternately on diets containing raw soya-bean flour $(R S F)$ or heated soya-bean flour (HSF) for 28 d each in a cross-over design*

(Mean values with their standard errors for six rats per group for $28 \mathrm{~d}$ )

\begin{tabular}{|c|c|c|c|c|c|}
\hline \multirow[b]{2}{*}{ Group } & \multicolumn{2}{|c|}{$\begin{array}{l}\text { Food conversion } \\
\text { efficiency ratio }\end{array}$} & \multicolumn{2}{|c|}{$\begin{array}{l}\text { Protein conversion } \\
\text { efficiency ratio }\end{array}$} & \multirow{2}{*}{$\begin{array}{c}\text { Statistical significance } \\
\text { of diet effects }\end{array}$} \\
\hline & Mean & SE & Mean & SE & \\
\hline \multicolumn{6}{|l|}{ Phase 1} \\
\hline C & 0.287 & 0.0144 & 1.435 & 0.0715 & C v. S1 $0.01>P>0.001$ \\
\hline SI† HSF & 0.219 & 0.0131 & 1.094 & 0.0656 & C v. S2 $P<0.001$ \\
\hline S2† RSF & 0.200 & 0.0090 & $1 \cdot 001$ & $0 \cdot 0450$ & S1 v. S2 $0.02>P>0.01$ \\
\hline \multicolumn{6}{|l|}{ Phase 2} \\
\hline & $0 \cdot 107$ & 0.0043 & 0.534 & 0.0214 & C v. S1 $P<0.001$ \\
\hline S1 RSF & 0.079 & 0.0039 & $0 \cdot 395$ & 0.0198 & C v. S2 $0.01>P>0.001$ \\
\hline S2 HSF & $0 \cdot 125$ & 0.0082 & 0.625 & 0.0406 & $\mathrm{~S} 1$ v. S2 $P<0.001$ \\
\hline \multicolumn{3}{|c|}{ Phase $1 v$. phase 2} & & & $\begin{array}{ll}\text { C } & P<0.001 \\
\text { S1 } & P<0.001 \\
\text { S2 } & P<0.001\end{array}$ \\
\hline
\end{tabular}

* For details of diets and procedures, see Table 1 and pp. 535-536.

$\uparrow$ Group S1 received the HSF diet during phase 1 and the RSF diet during phase 2; group S2 received the RSF diet during phase 1 and the HSF diet during phase 2. 

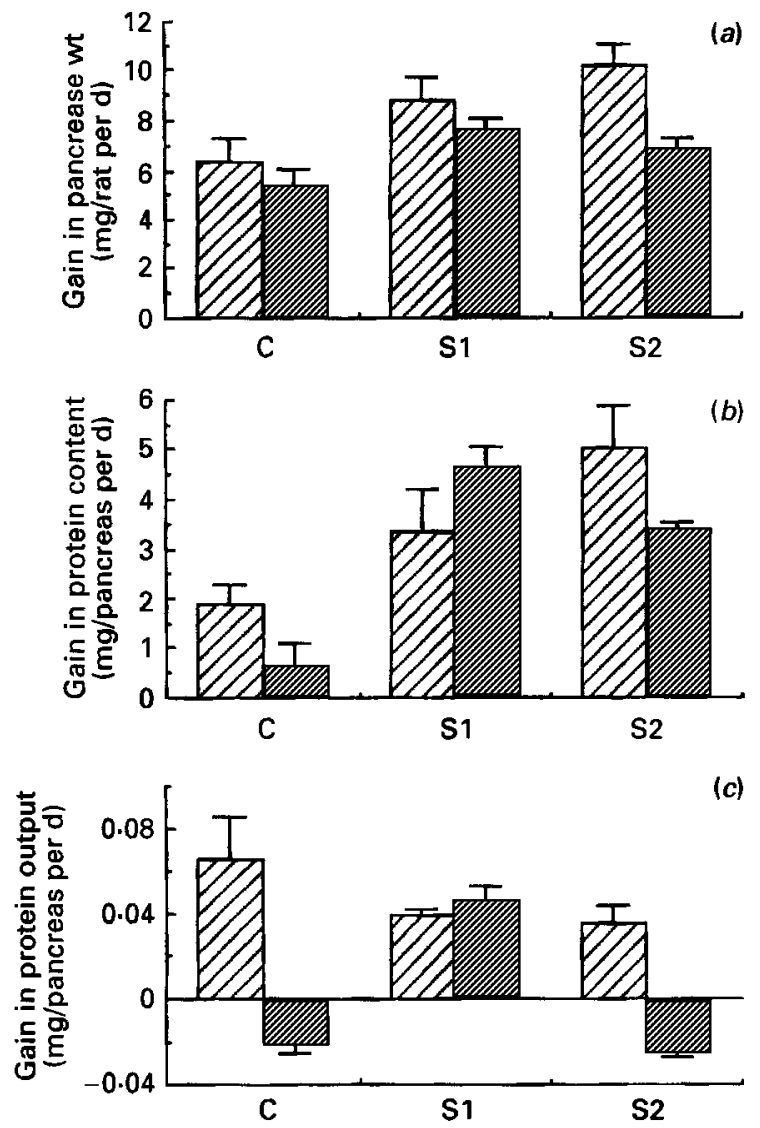

Fig. 2. Effect of alternate feeding of diets containing raw (RSF) or heated (HSF) soya-bean flour on daily gains in $(a)$ pancreas weight, $(b)$ pancreas protein content and $(c)$ pancreatic protein output in rats. Rats were given one

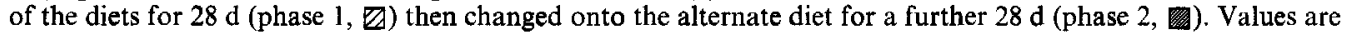
means with their standard errors indicated by vertical bars. C, control group, fed on a diet containing $200 \mathrm{~g}$ casein/ $\mathrm{kg}$ for $56 \mathrm{~d}$; S1 group, fed on the HSF diet during phase 1 and the RSF diet during phase 2; S2 group, fed on the RSF diet during phase 1 and the HSF diet during phase 2. For details of diets and procedures see Table 1 and pp. 534-536. Statistical analysis: panel $(a), \mathrm{C} v$. S1 $t 3.835,0.01>P>0.001 ; \mathrm{C} v$. S2 $t 2.166,0.05>P>$ 0.02 ; S1 v. S2 $t 4.621, P<0.001$ : panel $(b), \mathrm{C} v$. S1 $t 2.404,0.05>P>0.02 ; \mathrm{C} v$. S2 $t 2.939,0.01>P>0.001$; S1 v. S2 $t 3.561,0.01>P>0.001$ : panel $(c), \mathrm{C} v$. S1 $t 6.443, P<0.001 ; \mathrm{C} v$. S2 $t 1 \cdot 778$, not significant; S1 v. S2 t $2.68,0.02>P>0.01$.

Pancreas weights and protein contents and protein outputs in pancreatic juice (Fig. 2) At the end of phases 1 and 2 the relative pancreas weights (pancreas weight/body weight $\times 10^{3}$ ) were $1 \cdot 8,2 \cdot 0 ; 2 \cdot 8,3 \cdot 1 ; 3 \cdot 5,2 \cdot 5$, in groups $\mathrm{C}, \mathrm{S} 1$ and $\mathrm{S} 2$ respectively (results not shown). The values were correlated with daily gain in pancreas weight per rat $(6 \cdot 35,5 \cdot 35$; $8 \cdot 77,7 \cdot 58 ; 10 \cdot 23,6.85 \mathrm{mg}$, during phases 1 and 2 , in groups $\mathrm{C}, \mathrm{S} 1$ and $\mathrm{S} 2$ respectively) and the daily gain in protein contents $(1 \cdot 87,0.63 ; 3.33,4.62 ; 5.03,3.38$ in groups $C, S 1$ and $S 2$ respectively).

In the control group the daily gain in protein outputs was positive during phase 1 $(+0.065 \mathrm{mg} / \mathrm{d})$ and negative during phase $2(-0.021 \mathrm{mg} / \mathrm{d})$. During phase 1 the daily gain was similar in groups fed on soya-bean flours $(0.038$ and $0.035 \mathrm{mg} / \mathrm{d}$ in groups S1 and S2, respectively) but lower than that observed in the control group. During phase 2 the highest values were obtained in group $S 1(0.045 \mathrm{mg} / \mathrm{d})$, while values in group $\mathrm{S} 2(-0.025 \mathrm{mg} / \mathrm{d})$ were decreased and similar to those of the control group $(-0.03 \mathrm{mg} / \mathrm{d})$. 

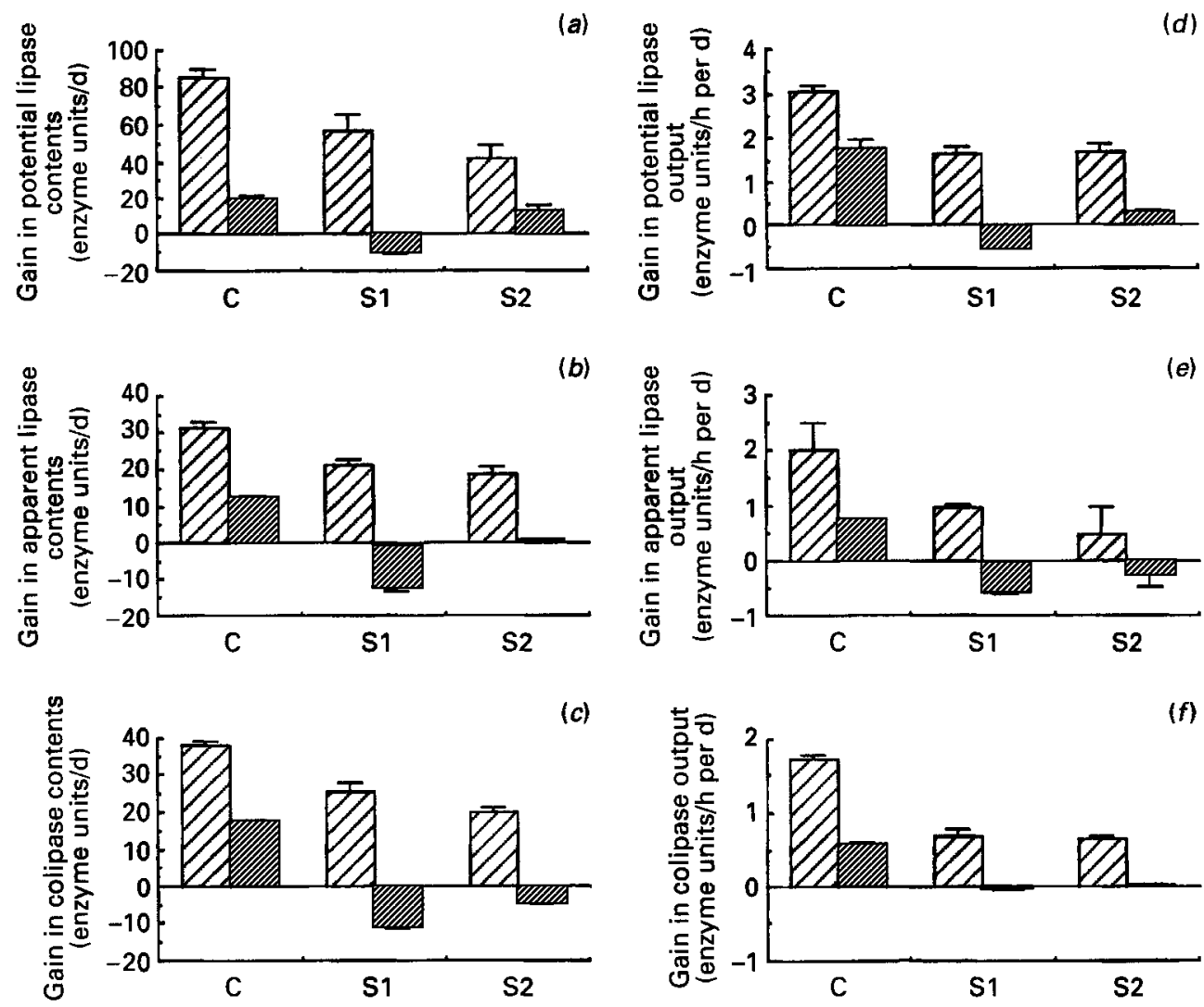

Fig. 3. Effect of alternate feeding of diets containing raw (RSF) or heated (HSF) soya-bean flour on (a) potential and $(b)$ apparent lipase $(E C$ 3.1.1.3), and (c) colipase activities in the pancreas (enzyme units/pancreas) and $(d$, $e, f)$ in pancreatic juice outputs (enzyme units/h per pancreas) of rats. Rats were given one of the diets for $28 \mathrm{~d}$ (phase 1, $\oslash$ ) then changed onto the alternate diet for a further $28 \mathrm{~d}$ (phase 2, 国). Values are means with their standard errors indicated by vertical bars. C, control group, fed on a diet containing $200 \mathrm{~g}$ casein $/ \mathrm{kg}$ for $56 \mathrm{~d} ; \mathrm{S} 1$ group, fed on the HSF diet during phase 1 and the RSF diet during phase 2 ; $\mathrm{S} 2$ group, fed on the RSF diet during phase 1 and the HSF diet during phase 2. For details of diets and procedures, see Table 1 and pp. 535-536. Statistical analysis: panel $(a), \mathrm{C} v$. S1 $t 5.39, P<0.001 ; \mathrm{C} v$. S2 $t 3.205,0.01>P>0.001$; S1 v. S2 $t 12.26$, $P<0.001$ : panel $(b)$, C v. S1 $t 7.974, P<0-001 ;$ C v. S2 $t 4.090, P<0.001$; S1 v. S2 $t 1.370$, not significant: panel $(c), \mathrm{C} v$. S $1 t 2.614,0.05>P>0.02 ; \mathrm{C} v$. S2 $t 2.959,0.01>P>0.001 ;$ S1 v. S2 $t 2.882,0.02>P>0.01$ : panel $(d), \mathrm{C} v$. S $1 t 3.27,0.01>P>0.001 ; \mathrm{C} v$. S2 $t 2.52,0.05>P>0.02 ; \mathrm{S} 1 v$. S2 $t 1.854$, not significant: panel (e), C v. S $1 t 5.862, P<0.001$; C v. S2 $t 6.181, P<0.001$; S1 v. S2 $t 1.558$, not significant: panel $(f)$, C v. S1 $t 5.65$, $P<0.001 ; \mathrm{C} v . \mathrm{S} 2 t 5.887, P<0.001 ; \mathrm{S} 1 v$. S $2 t 1 \cdot 75$, not significant.

\section{Digestive enzyme activities}

The Armitage \& Berry (1987) simple crossover design allows comparison of two groups during both phases of the experiment. In the control group the daily gain in all enzyme activities (contents and outputs) was higher during phase 1 than during phase 2 .

The daily gains in lipase (potential and apparent) and colipase activities in pancreas and in pancreatic juice were decreased in groups S1 and S2 compared with control values, but higher in groups S1 and S2 fed on the HSF diet compared with the RSF diet (Fig. 3).

In pancreatic juice during phases 1 and 2, colipase activity: potential lipase activity ratios were 0.54 (SE 0.08), 0.35 (SE 0.12); 0.42 (SE 0.03), 0.26 (SE 0.04) and 0.45 (SE 0.09), 0.27 (SE 0.02) in groups $\mathrm{C}, \mathrm{S} 1$ and $\mathrm{S} 2$ respectively (results not shown).

The highest daily gain in phospholipase $\mathrm{A}_{2}$ activity in the pancreas was obtained with the HSF diet, but pancreatic juice outputs were not correlated with pancreas contents (Fig. 

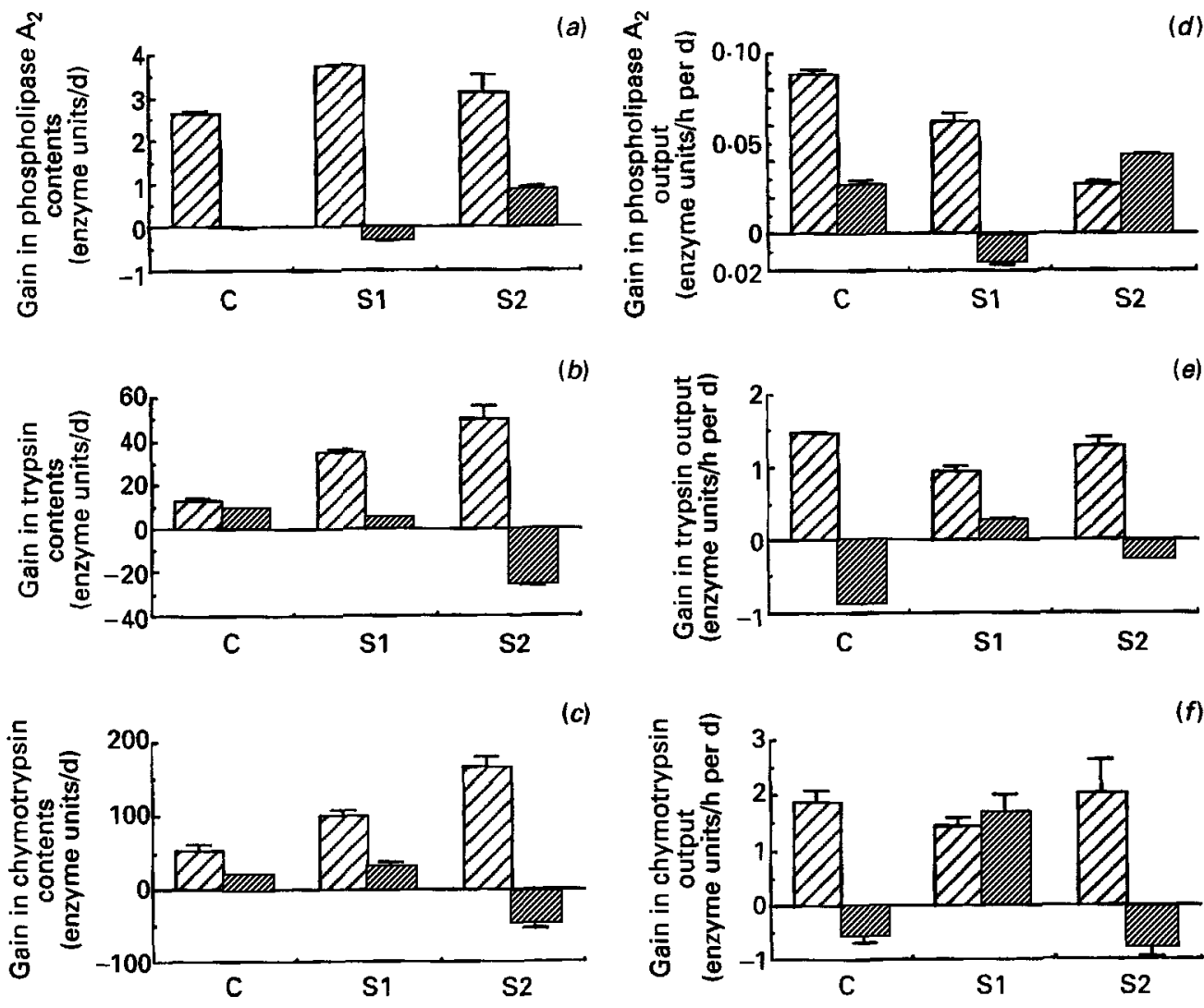

Fig. 4. Effect of alternate feeding of diets containing raw (RSF) or heated (HSF) soya-bean flour on (a) phospholipase $A_{2}(E C$ 3.1.1.4), (b) trypsin (EC 3.4.21.4) and (c) chymotrypsin (EC 3.4.21.1) activities in the pancreas (enzyme units/pancreas) and $(d, e, f)$ in pancreatic juice outputs (enzyme units $/$ h per pancreas) in rats. Rats were given one of the diets for $28 \mathrm{~d}$ (phase $1, \bigotimes$ ) then changed onto the alternate diet for a further $28 \mathrm{~d}$ (phase 2, 圈). Values are means with their standard errors indicated by vertical bars. C, control group, fed on a diet containing $200 \mathrm{~g}$ casein $/ \mathrm{kg}$ for $56 \mathrm{~d}$; Sl group, fed on the HSF diet during phase 1 and the RSF diet during phase $2 ; \mathbf{S} 2$ group, fed on the RSF diet during phase 1 and the HSF diet during phase 2 . For details of diets and procedures, see Table 1 and pp. 535-536. Statistical analysis: panel $(a), \mathrm{C} v$. S1 $t 2 \cdot 22,0.05>P>0 \cdot 02 ; \mathrm{C} v$. S2 $t 1.22$, not significant; S1 v. S2 $t 2.967,0.01>P>0.001: \operatorname{panel}(b)$, C v. S1 $t 3.443,0.01>P>0.001 ; \mathrm{C}$ v. S2 $t 3.249,0.01>P>0.001$; S1 v. S2 $t$ 13.649, $P<0.001$ : panel (c). C v. S1 $t 6.152, P<0.001$; C $v$. S2 $t 9.299$, $P<0.001 ;$ S1 v. S2 $t 3.076,0.01>P>0.001:$ panel $(d)$, C v. S $1 t 3.495,0.01>P>0.001 ;$ C v. S2 $t 2.529,0.05>$ $P>0.02 ;$ S1 v. S2 $t 1.75$, not significant: panel (e), C v. S1 $t 2.419,0.05>P>0.02 ; \mathrm{C} v$. S2 $t 2.293,0.05>P>$ 0.02 ; S1 v. S2 $t 2.545,0.05>P>0.02$ : panel $(f), \mathrm{C} v$. S1 $t 2 \cdot 186,0.05>P>0.02 ; \mathrm{C} v$. S2 $t 2.333,0.05>P>0.02$; S1 $v$. S2 $t 3 \cdot 21,0.01>P>0.001$.

4). The greatest gain in outputs was obtained in the control group during phase 1 and group S2 fed on the HSF diet during phase 2.

The higher daily gain in trypsin and chymotrypsin activities in the pancreas was observed in group S1 during phase 1 , and in the control group for trypsin, and group S1 for chymotrypsin activity during phase 2 (Fig. 4). Trypsin and chymotrypsin activities in pancreatic juice outputs were not correlated with those of pancreas contents.

\section{DISCUSSION}

A previous study has shown that the highest contents and outputs of hydrolase $/ \mathrm{g}$ pancreas are observed when control rats are 8-9 weeks old (Prost et al. 1988). In the present experiment, rat pancreas was subjected to maturation during phase 1 , correlated with larger 
body and pancreas growth. Rats were adult during phase 2 with lower body and pancreas growth (Figs. 1, 2).

The Armitage \& Berry (1987) simple crossover design test was used to compare the effects of alternate RSF and HSF diets on S1 and S2 rats at the same age, during the same growth period. Control values were also compared with $\mathrm{S} 1$ and $\mathrm{S} 2$ values with this test. Feeding rats alternately with RSF or HSF diets allowed differentiation between the effects of heat-stable and heat-labile factors in soya-bean flour on pancreatic enzyme synthesis and secretion. The original aspect of this study is the comparison of activities for each enzyme in pancreatic tissue and juice in the same rat.

S1 and S2 groups fed on both soya-bean diets (raw and heated) showed slow growth which was correlated with reduction in food and $\mathrm{N}$ intakes and $\mathrm{N}$ balance, particularly with the RSF diet (Table 2). The reduction in food intake was dependent on different factors. The RSF diet contains a trypsin inhibitor which slows down the gastric transit of ingested food (De Mulanaere, 1964) and stimulates CCK release (Green et al. 1986). Brand \& Morgan (1981) have shown that oral administration of trypsin inhibitor to rats is followed by a great CCK peak in plasma. The increase in plasma CCK may strongly inhibit stomach emptying (Green et al. 1986). Moreover, soya-bean proteins generally, and protease inhibitors particularly, are not easily digested by the gastrointestinal tract of rats (Kakade et al. 1973).

The relative pancreas weight of rats fed on both soya-bean diets, particularly those subjected to the RSF diet, was higher than that of control rats. This increase and its consequences have been reviewed by Gumbmann et al. (1986). Prolonged feeding with soya-bean flour containing trypsin inhibitor induces chronic CCK release in excessive amounts and pancreatic hypertrophy. Temler \& Mettraux (1986) have shown that the increase in gastrin activity of rats fed on soya-bean trypsin inhibitor also contributes to pancreatic hypertrophy. Moreover, soya-bean flour contains various antinutritional factors such as lectins which are thermostable and resistant to proteolytic breakdown, and induce cellular hyperplasia and pancreatic hypertrophy in spite of heat treatment (Grant et al. 1987).

Hypersecretion of pancreatic proteases, namely cysteine-rich trypsin and chymotrypsin, enhances the requirement for S-containing amino acids in the synthesis of pancreatic hydrolases. Growth retardation could be attributable to the fact that cysteine and methionine would be less available for protein synthesis (Crass \& Morgan, 1982). In the present study, soya-bean proteins were less suitable than casein for protein synthesis as shown by the nutritional efficiency of soya-bean proteins (Table 3) which was lower than that of casein.

Determination of apparent lipid digestibility indicated that rats fed on soya-bean diets (raw or heated) increased their lipid faecal excretion. This diminution in lipid digestibility could be attributable to an intraluminal lipolytic activity decrease, on account of the presence of amphiphilic soya-bean proteins (Gargouri et al. 1984) and a diminished colipase activity:potential lipase activity ratio observed in the pancreatic juice of rats fed on HSF and RSF. A positive correlation between values of apparent lipid digestibility and colipase:lipase ratios was observed. The highest correlation values observed during phases 1 and 2 of the experiment were obtained with the control diet, followed by RSF and HSF.

The RSF and HSF diets depressed lipase and colipase activities, and to a lesser extent phospholipase $A_{2}$ activity in the pancreas and its secretion. Adaptation of pancreatic enzyme synthesis to diet composition was well demonstrated. Lipase and phospholipase $\mathrm{A}_{2}$ activities are enhanced when the diet is enriched with triacylglycerols (Belleville et al. 1978). The decrease in lipid digestibility with raw or heated soya-bean diets at least partly accounts for the depression in lipolytic activity. It could be hypothesized from in vitro data reported by Gargouri et al. (1984) and from the present observations that amphiphilic soya- 
bean proteins cause partial inhibition of in vivo dietary fat hydrolysis by pancreatic lipase and colipase. Moreover, previous studies have shown that HSF causes a partial inhibition of lipase and colipase activities (Khalifa et al. 1992). In the gut, bile salts and proteins lead to inactivation of lipase by physical separation of the enzyme from its substrate. This inhibition is reversed by colipase which forms a specific complex with lipase and brings the enzyme into close contact with the interface, thus indirectly allowing interfacial activation (Van Tilbeurgh et al. 1992). Under these conditions it could be hypothesized that colipase is the limiting factor of lipase activity in the intestinal tract. This, in turn, might cause a decrease in the plasma concentration of metabolites resulting from the cellular degradation of fatty acids. Metabolites such as $\alpha$-acetoacetate and $\beta$-hydroxybutyrate are considered by Lavau et al. (1974) to be mediators of pancreatic lipase synthesis. However, our results indicated that the decrease in lipid digestibility was lower $(-18$ and $-11 \%$ for S2 and S1 respectively, during phase 1 and $-6 \%$ during phase 2 ) than that observed in lipase and colipase activities (nearly $-40 \%$ for potential and apparent lipase, and $-60 \%$ for colipase outputs for RSF and HSF during phases 1 and 2). This could account for the secretion of excess lipolytic enzymes in pancreatic juice under normal conditions.

Only a few studies have been carried out on the changes in lipase, colipase and phospholipase $A_{2}$ activities in pancreas and pancreatic juice, brought about by alternate feeding of a diet containing raw and heated soya-bean flours. Konijn et al. (1970) have shown that the pancreatic lipolytic activity is higher in rats adapted to a HSF diet than in rats fed on the RSF diet. Raw proteins have greater solubility than heated proteins (De Muelenaere, 1964) in the intestinal tract and this could modify the interaction between the enzyme and its substrate. However, the decrease in lipase and colipase activities was induced by heat-labile as well as heat-stable factors since it was observed in rats fed on both RSF and HSF diets. These factors cannot be the same as those inhibiting in vitro lipase activity (Satouchi \& Matsushita, 1976; Gargouri et al. 1984), since they affect lipase and colipase biosynthesis and secretion.

In conclusion, alternate feeding of RSF and HSF diets in the rat allowed study of the effects of heat-stable and heat-labile factors in soya-bean flour respectively, on the synthesis and secretion of pancreatic digestive enzymes. The most striking effect of feeding soya-bean flour diets was the net decrease in lipase and colipase activities in pancreatic tissue and juice. Phospholipase $\mathrm{A}_{2}$ activities were less affected. In contrast, protease levels were increased.

So far, the mechanism by which factors in soya-bean flour influence the synthesis of enzymes in the pancreas has been unknown. Control of the pancreatic secretion composition by diet may not only be attributable to CCK but to other intestinal hormones together with metabolites resulting from the transformation of nutrients. Moreover, our results indicate non-parallelism in the enzyme activities of pancreas and its secretion, suggesting changes in enzyme retention thresholds in acinar cells which vary with RSF or HSF diets.

We are indebted to Anne Magnet, a linguist at the University of Burgundy, for editing the manuscript. This work was supported by the French Foreign Office with International Research Extension Grants 86 MES 25 and by the Research and PH.D Studies Office (D.R.E.D) EA DRED 564.

\section{REFERENCES}

Armitage, P. \& Berry, P. (1987). Statistical Methods in Medical Research, 2nd ed., pp. 222-226. Oxford: Blackwell Scientific Publications.

Belleville, J. \& Clement, J. (1971). Effets de facteur nutritionnels et hormonaux sur l'activite phospholipasique $\mathrm{A}_{2}$ du suc pancréatique chez le rat éveillé (Effects of nutritional and hormonal factors on pancreatic juice phospholipase $\mathrm{A}_{2}$ activity in the conscious rat). Archives des Sciences Physiologiques 25, 59-83.

Belleville, J., Prost, J. \& Gillet, M. (1978). Effets de regimes riches en triglycérides et en phospholipides sur les activités de la lipase et de la phospholipase $A_{2}$ du suc pancréatique et du pancréas de rat (Effects of diets enriched with triacylglycerols or phospholipids on lipase and phospholipase $\mathbf{A}_{2}$ activities in rat pancreatic juice and pancreas). Archives Internationale de Physiologie et de Biochimie 86, 631-643. 
Brand, S. J. \& Morgan, R. G. H. (1981). The release of rat intestinal cholecystokinin after oral trypsin inhibitor measured by bio-assay. Journal of Physiology (London) 319, 325-343.

Canioni, P., Julien, R., Rathelot, J. \& Sarda, L. (1977). Pancreatic and microbial lipases: a comparison of the interaction of pancreatic colipase with lipases of various origins. Lipids 12, 393-397.

Colwell, A. R. (1951). Collection of pancreatic juice from rats and consequences of its continued loss. American Journal of Physiology 164, 812-821.

Council of European Communities (1986). Directives of the council concerning animal protection for the use of living animals in scientific investigations. Official Journal of European Communities, 86/609, L358, 1-28.

Crass, R. A. \& Morgan, R. G. H. (1982). The effect of long-term feeding of soya-bean flour on pancreatic growth in the rat. British Journal of Nutrition 47, 119-129.

De Muelenaere, H. J. (1964). Studies on the digestion of soybeans. Journal of Nutrition 82, 197-205.

Figarella, C. (1966). Composition et stabilité de l'équipement enzymatique du pancréas de l'homme et de divers animaux, (Composition and stability of pancreatic enzyme secretions of humans and various animals). Bulletin de la Société de Chimie Biologique 48, 97-115.

Folch, J., Lees, M. \& Sloane Stanley, G. H. (1957). Simple method for isolation and purification of total lipids from animal tissues. Journal of Biological Chemistry 226, 497-509.

Gargouri, Y., Julien, R., Pieroni, G., Verger, R. \& Sarda, L. (1984). Studies on the inhibition of pancreatic and microbial lipases by soybean proteins. Journal of Lipid Research 25, 1214-1221.

Grant, G., Watt, W. B., Stewart, J. C. \& Pusztai, A. (1987). Effects of dietary soyabean (Glycine max) lectin and trypsin inhibitors upon the pancreas of rats. Medical Sciences and Research in Biochemistry 15, 1197-1205.

Green, G. M., Van Levan, H. \& Liddle, R. A. (1986). Plasma CCK and pancreatic growth during adaptation to dietary proteins. American Journal of Physiology 251, G70-G74

Gumbmann, M. R., Spangler, W. L., Dugan, G. M. \& Rackis, J. J. (1986). Safety of trypsin inhibitors in the diet: effects on the rat pancreas of long-term feeding of soy flour and soy protein isolate. Advances in Experimental Medicine and Biology 199, 33-77.

Kakade, M. L., Hoffa, D. E. \& Liener, I. E. (1973). Contribution of trypsin inhibitors to the deleterious effect of unheated soyabean fed to rats. Journal of Nutrition 103, 1172-1177.

Khalifa, F., Bertrand, V., Belleville, J., Sarda, L. \& Prost, J. (1992). Short term effect of feeding raw or heated soya flour and casein meals on lipid intestinal digestion and absorption in rat. Journal of Nutritional Biochemistry 3, 224-231.

Konijn, A. M., Birk, Y.\& Gugenheim, K. (1970). Pancreatic enzyme pattern in rats as affected by dietary soyabean flour. Journal of Nutrition 100, 361-368.

Lavau, M., Bazin, R. \& Herzog, J. (1974). Comparative effect of oral and parenteral feeding on pancreatic enzymes in the rat. Journal of Nutrition 104, 1432-1437.

Liener, I. E. (1981). Factors affecting the nutritional quality of soya products. Journal of the American Oil Chemist's Society 58, 406-415.

Liener, I. E. \& Kakade, I. E. (1980). Protease inhibitors. In Toxic Constituents of Plant Foodstuffs, pp. 7-71 [I. E. Liener, editor]. New York: Academic Press.

Lowry, O. H., Rosebrough, N. J., Farr, A. L. \& Randall, R. J. (1951). Protein measurement with the Folin phenol reagent. Journal of Biological Chemistry 193, 265-275.

MacGuiness, E. E., Morgan, R. G. \& Wormsley, K. G. (1984). Effects of soybean flour on the pancreas of rats. Environmental Health Perspectives 56, 205-212.

Naim, H., Gertler, A. \& Birk, Y. (1982). The effect of dietary raw and autoclaved soya-bean protein fractions on growth, pancreatic enlargement and pancreatic enzymes in rats. British Journal of Nutrition 47, $281-288$.

Ouagued, M. \& Girard-Globa, A. (1980). A rapid and reliable method for determination of colipase. Biochimie 64, 301-302.

Prost, J., Belleville, J. \& Valantin-Rollet, C. (1988). Effects of age and protein malnutrition followed by a balanced diet on the non-parallel change in digestive enzymes in the pancreas and their secretion in the rat. British Journal of Nutrition 60, 619-625.

Rackis, J. J. (1981). Significance of soya trypsin inhibitors in nutrition. Journal of the American Oil Chemist's Society 58, 495-500.

Rathelot, J., Julien, R., Canioni, P., Coeroli, C. \& Sarda, L. (1975). Studies on the effect of bile salts and colipase on enzymatic lipolysis. Improved method for the determination of lipase and colipase. Biochimie 57, 1117-1120.

Satouchi, K. \& Matsushita, S. (1976). Purification and properties of lipase inhibiting protein from soybean cotyledon. Agricultural and Biological Chemistry 40, 889-897.

Temler, R. S. \& Mettraux, C. (1986). Gastrin and cholecystokinin levels in rats fed soya bean trypsin inhibitor. Advances in Experimental Medicine and Biology 199, 133-141.

Van Tilbeurgh, H., Sarda, L., Verger, R. \& Cambillau, C. (1992). Structure of the pancreatic lipase-procolipase complex. Nature 359, 159-162.

Widmer, F. (1977). Pancreatic lipase effectors extracted from soyabean meal. Journal of Agricultural and Food Chemistry 25, 1142-1145. 